\title{
Penggunaan Alat Peraga Sederhana SISI MISTIS dalam Pembelajaran Listrik Statis
}

\author{
Jaka Afriana \\ SMP Negeri 6 Sambas \\ Jalan Raya Gapura Kabupaten Sambas Provinsi Kalimantan Barat \\ Email: jakafisika04@gmail.com
}

\begin{abstract}
Listrik statis merupakan konsep IPA yang bersifat abstrak, khususnya perpindahan elektron yang menyebabkan suatu benda bermuatan. Elektron tidak bisa dilihat, hanya bisa dimodelkan. Alat peraga sederhana (APS) Simulasi Muatan Listrik Statis (SISI MISTIS) diharapkan dapat mengkonkritkan elektron yang berpindah sehingga membuat benda bermuatan setelah digosok/geser. Penelitian ini bertujuan untuk mengetahui pemahaman peserta didik tentang konsep listrik statis melalui pembelajaran menggunakan APS SISI MISTIS, mengetahui keefektifan APS SISI MISTIS dalam pembelajaran, dan mendeskripsikan respon peserta didik terhadap pembelajaran listrik statis menggunakan APS SISI MISTIS. Hasil yang dicapai dalam pembelajaran yaitu : (I) Uji statistik McNemar dan dilanjutkan tes Binomial diperoleh rata-rata keseluruhan 3,89 (perubahan signifikan); (2) keefektifan APS SISI MISTIS dalam pembelajaran bagi peserta didik tergolong sedang dengan rata-rata harga efek size sebesar 0,53; (3) respon positif peserta didik terhadap pembelajaran listrik statis menggunakan APS SISI MISTIS diperolehan skor rata-rata $86,02 \%$ dari kriteria yang diharapkan..
\end{abstract}

Kata kunci: alat peraga sederhana, listrik statis

\section{PENDAHULUAN}

Kegiatan pembelajaran sebagai bagian dari proses pendidikan, sering mendapatkan beberapa masalah yang menjadi penghambat majunya pendidikan. Diantaranya adalah kurangnya motivasi belajar peserta didik, yang berakibat pada rendahnya hasil belajar, sehingga berakibat pada rendahnya mutu lulusan sekolah. Rendahnya motivasi dan mutu pendidikan dikarenakan dalam proses pembelajaran guru belum membuat peserta didik belajar mandiri menemukan sendiri konsep maupun fakta yang diperoleh dalam kehidupan sehari-hari. Fenomena gejala alam yang sering dialami peserta didik dipelajari di sekolah melalui pembelajaran Ilmu Pengetahuan Alam (IPA).

Mata pelajaran IPA perlu diberikan kepada semua peserta didik untuk memperoleh kompetensi dasar ilmu pengetahuan dan teknologi serta membudayakan berpikir ilmiah secara kritis, kreatif dan mandiri [I]. Muatan kurikulum tingkat satuan pendidikan kelompok mata pelajaran ilmu pengetahuan dan teknologi pada Sekolah Menengah Pertama (SMP) dimaksudkan untuk memberikan pengetahuan dan keterampilan kepada peserta didik untuk menguasai dasar-dasar sains dalam upaya penguasaan iptek. Pada kurikulum 20I3, pembelajaran IPA menekankan pada penguasaan konsep dan percobaan [2]. Karena itu, pembelajaran IPA di sekolah harus menekankan pada penguasaan konsep melalui percobaan sederhana yang dilakukan oleh peserta didik sendiri.

Percobaan atau eksperimen dalam pembelajaran IPA merupakan langkah konkrit guru dalam menghadirkan fakta-fakta keilmuan dalam pembelajaran. Pembuktian fakta ilmuan ada yang bersifat nyata maupun abstrak. Dalam pembelajaran IPA, ada beberapa kompetensi dasar (KD) yang bersifat abstrak, seperti cahaya, dan listrik. Pembelajaran materi cahaya dan listrik memerlukan media visualisasi agar mudah dipahami peserta didik. Konsep listrik dirasakan cukup sulit dipahami oleh peserta didik, karena listrik yang terlihat adalah efek dari peristiwa listrik[3].

Contoh gejala listrik statis, bagaimana sebuah benda bermuatan listrik netral, postif, atau negatif. Apabila dua benda digosok, maka akan terjadi pengurangan atau penambahan elektron. Tetapi elektron yang berpindah bersifat abstrak sehingga tidak bisa dilihat langsung oleh peserta didik. Terlebih lagi, materi listrik statis termuat dalam kisi-kisi ujian nasional dengan indikator menjelaskan gejala listik statis dalam penerapan kehidupan sehari-hari. 
Hal ini yang dirasakan peneliti sebagai masalah yang harus dicari jalan keluarnya. Guru harus mengupayakan pembelajaran listrik statis yang bersifat abstrak menjadi konkrit dengan bantuan Alat Peraga Sederhana (APS).

Dalam upaya mengadakan APS IPA tersebut, guru dan atau dengan peserta didik dapat melakukan pengembangan dengan cara merancang dan membuat alat peraga IPA sederhana (buatan sendiri). Produk pengembangan APS IPA walaupun sederhana dalam tampilan fisik, tetapi dapat mendukung prinsip kerja dan konsep IPA yang diajarkannya sehingga tidak menimbulkan miskonsepsi.

Dalam memperbaiki proses pembelajaran listrik statis di SMP Negeri 6 Sambas guru berupaya membuat alat peraga sederhana untuk memudahkan peserta didik dalam memahami konsep listrik statis dengan menggunakan Alat Peraga Sederhana (APS) Simulasi Muatan Listrik Statis (SISI MISTIS) dengan bantuan lembar kerja peserta didik. Prinsip APS SISI MISTIS untuk melihat simulasi proses perpindahan elektron pada dua benda yang digosok dan menentukan jenis muatan listrik benda/bahan. Penelitian ini dilakukan pada pembelajaran listrik statis menggunakan alat peraga sederhana SISI MISTIS di SMP Negeri 6 Sambas.

\section{KAJIAN PUSTAKA}

Alat peraga didefinisikan sebagai alat bantu untuk mendidik atau mengajar supaya konsep yang diajarkan guru mudah dimengerti oleh siswa dan menjadi alat bantu dalam proses pembelajaran yang dibuat oleh guru atau peserta didik dari bahan sederhana yang mudah didapat dari lingkungan sekitar [4]. Alat ini berfungsi untuk membantu mempermudah dalam mencapai kompetensi pembelajaran.

Alat peraga sederhana (APS) SISI MISTIS diharapkan dapat mengkonkritkan elektron yang berpindah sehingga membuat benda bermuatan setelah digosok/geser. Dengan melakukan sendiri dan bekerja dalam kelompok, peserta didik akan lebih mudah memahami sesuai dengan tujuan yang diharapkan dalam pembelajaran.

Beberapa hal penting diperhatikan sebagai kriteria dalam pembuatan dan pengembangan alat peraga sederhana sebagai berikut. (I). bahan mudah diperoleh (diantaranya dengan memanfatkan limbah, diminta, atau dibeli dengan harga relatif murah); (2). mudah dalam perancangan dan pembuatannya; (3). mudah dalam perakitannya (tidak memerlukan keterampilan khusus); (4). mudah dioperasikannya; (5). dapat memperjelas/menunjukkan konsep dengan lebih baik; (6). dapat meningkatkan motivasi peserta didik; (7). akurasi cukup dapat diandalkan; (8). tidak berbahaya ketika digunakan; (9). Menarik; (I0). daya tahan alat cukup baik (lama pakai); (II). inovatif dan kreatif; dan (I2). bernilai pendidikan [5].

Listrik statis merupakan konsep IPA yang bersifat abstrak, khususnya perpindahan elektron yang menyebabkan suatu benda bermuatan. Elektron tidak bisa dilihat, hanya bisa dimodelkan. Dalam proses pembelajaran menggunakan metode eksperimen, peserta didik hanya bisa melihat interaksi benda bermuatan setelah digosok. Sedangkan perpindahan muatan sangat sulit dibuktikan secara langsung. Sejauh ini, peneliti hanya menemukan simulasi muatan listrik statis menggunakan sofware komputer. Bisa dalam bentuk media presentasi powerpoint, macromedia flash, atau program aplikasi yang lain.

SISI MISTIS dibuat sendiri oleh peneliti dengan tujuan mempermudah peserta dalam memahami konsep perpindahan elektron yang menyebabkan benda bermuatan listrik. Dalam proses pembelajaran, peserta didik dibagi dalam kelompok yang heterogen terdiri dari peserta didik laki-laki dan perempuan. Agar memudahkan peserta didik bekerja dalam kelompok, SISI MISTIS dilengkapi dengan Lembar Kerja Peserta Didik (LKPD). Dengan adanya LKPD, diharapkan setiap anggota kelompok dapat kerjasama dengan baik.

Uji kelayakan APS SISI MISTIS menggunakan 8 aspek kelayakan, yakni : bahan mudah diperoleh, mudah dalam perancangan dan pembuatannya, mudah dalam perakitannya (tidak memerlukan keterampilan khusus), mudah dioperasikan, dapat memperjelas / menunjukkan konsep dengan lebih baik, dapat meningkatkan motivasi peserta didik, sesuai dengan perkembangan intelektual peserta didik, dan estetika/menarik. Bentuk alat peraga sederhana SISI MISTIS dapat dilihat seperti gambar berikut.

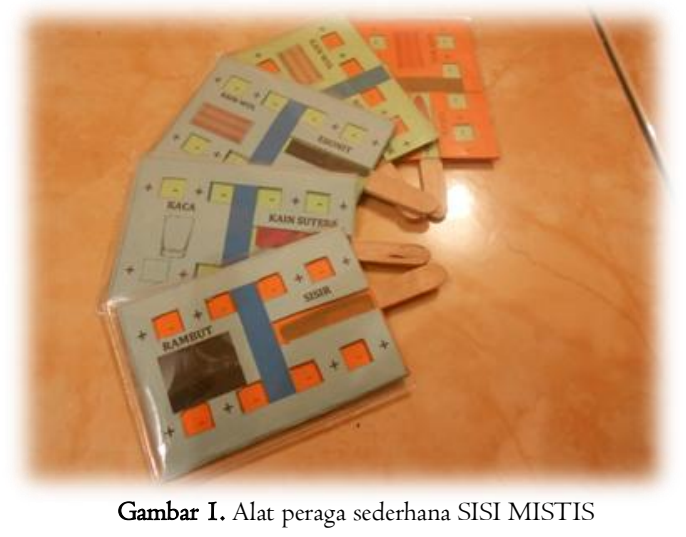

\section{METODE PENELITIAN/EKSPERIMEN}

Penelitian ini bertujuan untuk mengetahui perubahan hasil belajar, Keefektifan, dan respon peserta didik menggunakan APS SISI MISTIS setelah diberikan perlakuan kepada satu kelompok peserta didik, rancangan 
One Group Pre-test-Posttest Design [6] digunakan dalam penelitian ini. Rancangan ini digunakan untuk satu kelompok subjek dengan melakukan pengukuran lalu dikenakan perlakuan, yaitu pembelajaran menggunakan APS SISI MISTIS dan diakhiri dengan pengukuran untuk kedua kalinya. Rancangan dapat digambarkan sebagai berikut :

Rancangan One Group Pre-test-Posttest Design

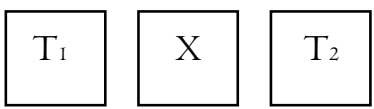

Keterangan :

$T_{I}$ : Tes awal yang diberikan kepada peserta didik sebelum diberikan perlakuan

$\mathrm{X}$ : Perlakuan (pembelajaran menggunakan APS SISI MISTIS)

$\mathrm{T}_{2} \quad$ : Tes akhir yang diberikan kepada peserta didik setelah diberikan perlakuan

Penelitian ini dilakukan di SMP Negeri 6 Sambas pada tahun pelajaran 2013/20I4 dengan mengambil peserta didik Kelas IX menjadi subjek penelitian. Kelas IX hanya terdiri dari I (satu) kelas berjumlah 27 peserta didik, terdiri dari I6 peserta didik laki-laki dan II peserta didik perempuan.

Alat ukur dalam penelitian (instrumen)[7] dalam penelitian ini digunakan 2 (dua) instrumen penelitian yaitu : (I) soal pre-test dan post-test untuk mengetahui pemahaman peserta didik sebelum dan sesudah diberikan perlakuan menggunakan alat peraga sederhana SISI MISTIS. Soal pre-test dan post-test dikembangkan peneliti dengan membuat indikator soal yang sama dengan soal ujian akhir nasional tahun-tahun sebelumnya. Soal pre-test dan post-test berupa tes pilihan ganda sebanyak I6 soal dengan 3 (tiga) indikator soal; (2) angket respon skala likert yang bersifat mengukur. Angket berupa pernyataan tertutup dengan empat pilihan wajib, yaitu sangat setuju, setuju, tidak setuju, dan sangat tidak setuju. Selain pilihan wajib, peserta didik juga diminta untuk menuliskan komentar dan saran. Bentuk skala sikap dari Likert berupa pertanyaan atau pernyataan yang jawabannya dalam bentuk skala persetujuan atau penolakan terhadap pertanyaan atau pernyataan [8].

\section{HASIL PENELITIAN DAN PEMBAHASAN}

Pemahaman peserta didik terhadap konsep listrik statis dilihat dari jumlah kesalahan dalam menjawab soal pre-test dan post-test. Selisih penurunan jumlah kesalahan jawaban sebelum dan setelah pembelajaran menggunakan APS SISI MISTIS merupakan peningkatan pemahaman peserta didik.
Penggunaan APS SISI MISTIS dalam pembelajaran listrik statis menghasilkan perubahan penurunan kesalahan yang positif (semakin faham). Rata-rata kesalahan pada pretest 8,8I dan menurun pada post-test menjadi 4,30 seperti yang disajikan pada grafik berikut.

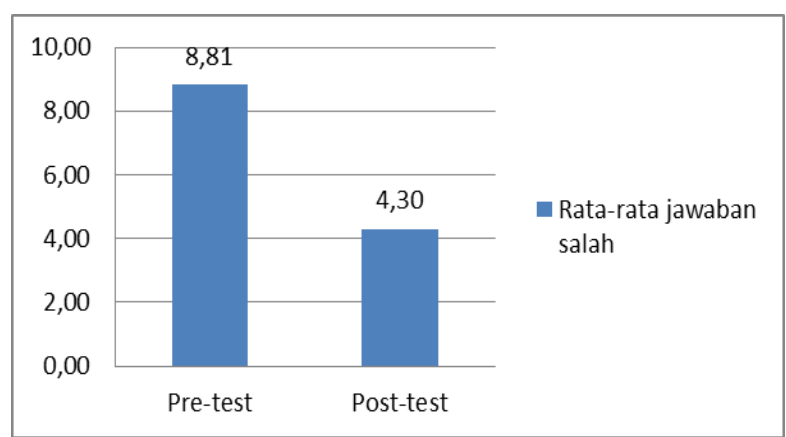

Gambar 2. Rata-rata jawaban salah peserta didik

Jika dibuat persentase, kesalahan menjawab soal pre-test $55,06 \%$, setelah diberikan pembelajaran menggunakan APS SISI MISTIS menjadi 26,87 \% atau selisih 28,18\% dengan uji statistik McNemar dan dilanjutkan tes Binomial diperoleh rata-rata keseluruhan 3,89 (perubahan signifikan).

Pembelajaran listrik statis tentang pemahaman konsep terdapat pada materi struktur atom, memberi muatan listrik benda, dan interaksi muatan listrik. Ketiga indikator ini tertuang dalam soal pretest dan postest sesuai dengan soal yang muncul pada ujian nasional tahun-tahun sebelumnya. Setelah dilakukan analisis data ternyata APS SISI MISTIS efektif digunakan dalam pembelajaran listrik statis. Setiap peserta didik mengalami penurunan kesalahan dalam menjawab soal pretest dan postest

APS SISI MISTIS dikatakan efektif untuk peserta didik dalam memahami konsep listrik statis pada tingkat sedang sampai tinggi. Dapat disimpulkan bahwa, 22 dari 27 atau $(81,48 \%)$ peserta didik telah memahami konsep listrik statis seperti yang diperlihatkan pada grafik berikut.

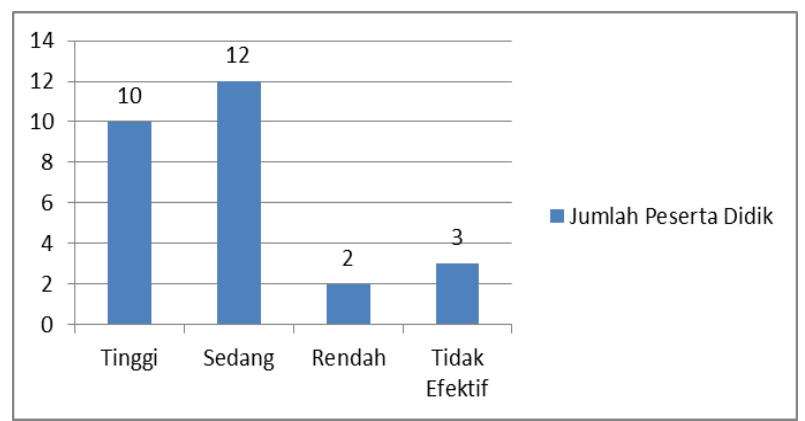

Gambar 3. Keefektifan APS SISI MISTIS tiap peserta didik 
Peserta didik merasa senang jika belajar menggunakan SISI MISTIS $84,26 \%$, peserta didik merasa tertarik untuk memahami materi IPA 85,19 \%, belajar dengan SISI MISTIS dapat membantu mempelajari materi / bahan ajar 86,II \%, belajar dengan SISI MISTIS dapat membentuk sikap kreatif 86,II \%, belajar dengan SISI MISTIS dapat dijadikan wadah untuk memahami konsep lebih sederhana dan praktis $89,81 \%$, peserta didik semakin faham dengan pembelajaran IPA 82,4I \%, peserta didik senang dengan penilaian guru terhadap hasil kerjanya $84,26 \%$, peserta didik yakin akan dapat berhasil mengikuti kegiatan pembelajaran jika belajar sungguh-sungguh 93,52\%, peserta didik dapat menyelesaikan tugas-tugas dalam pembelajaran $78,70 \%$, dan pembelajaran menggunakan SISI MISTIS perlu diterapkan di sekolah 89,8I \%.

\section{KESIMPULAN}

Secara keseluruhan, simpulan dalam penelitian ini adalah : (I). Berdasarkan uji McNemar ditemukan perubahan positif dalam pembelajaran diperoleh rata-rata $\chi^{2}$ hitung $=6,72$ dengan harga $\chi_{\text {tabel }}^{2}=3,84\left(\chi_{\text {tabel }}^{2}<\chi^{2}\right.$ hitung). Sedangkan untuk indikator struktur atom dan sifat muatan listrik; dan interaksi muatan listrik tidak signifikan denga rata-rata $\chi^{2}$ hitung 2,9I dan 2,05; (2). keefektifan APS SISI MISTIS dalam pembelajaran listrik statis bagi peserta didik tergolong sedang dengan rata-rata harga efek size sebesar 0,53; (3). respon positif peserta didik terhadap pembelajaran listrik statis menggunakan APS SISI MISTIS diperolehan skor rata-rata 86,02 \% dari kriteria yang diharapkan. Komentar peserta didik yaitu : lebih sederhana dan praktis belajar IPA, senang belajar menggunakan APS SISI MISTIS, paham dengan materi yang disampaikan, dan memotivasi dalam belajar. Sedangkan saran yang diberikan yaitu : perlu diterapkan baik di sekolah maupun sekolah lain agar belajar IPA lebih mudah, dan setiap mata pelajaran sebaiknya menggunakan media/alat peraga.

\section{Ucapan Terimakasih}

Ucapan terima kasih kepada Wahyudi, M. Pd, M. Si selaku dosen Fisika IKIP PGRI Pontianak yang telah memberikan kontribusi terkait dengan publikasi ini.

\section{Kepustakaan}

[I] Departemen Pendidikan Nasional, Kurikulum Tingkat Satuan Pendidikan SMP/MTs, Jakarta BSNP, 2006

[2] Kemdikbud, Kerangka Dasar dan Struktur Kurikulum 20I3, Jakarta Kemdikbud, 2013
[3] Afriana, Jaka, Miskonsepsi Buku Ajar Fisika SMP Kelas IX Tentang Rangkaian Listrik Arus Searah yang Banyak Dipakai di Pontianak, Skripsi Program Sarjana, Pontianak Universitas Tanjungpura, 2008

[4] Widiyatmoko, A., dan Pamelasari, S.D, Pembelajaran Berbasis Proyek untuk Mengembangkan Alat Peraga IPA dengan Memanfaatkan Bahan Bekas Pakai, Jurnal Pendidikan IPA Indonesia, Vol I edisi I, 20I2, hal 5I - 56

[5] Dirjen Pembinaan SMA, Pedoman Pembuatan Alat Peraga Kimia Untuk SMA, 20II. Website: http://psma.kemdikbud.go.id/files/ Buku_Alat_Peraga_Kimia.pdf diakses tanggal 2 November 2013

[6] Suryabrata, Sumadi, Metodologi Penelitian, Jakarta Rajawali Pers, 2005

[7] Sugiyono, Metode Penelitian Pendidikan (Pendekatan Kauntitatif, Kualitatif, dan $R \& D$ ), Bandung Alfabeta, 2013

[8] Sukmadinata, Nana Syaodih, Metode Penelitian Pendidikan, Bandung PT Remaja Rosdakarya, 2010 